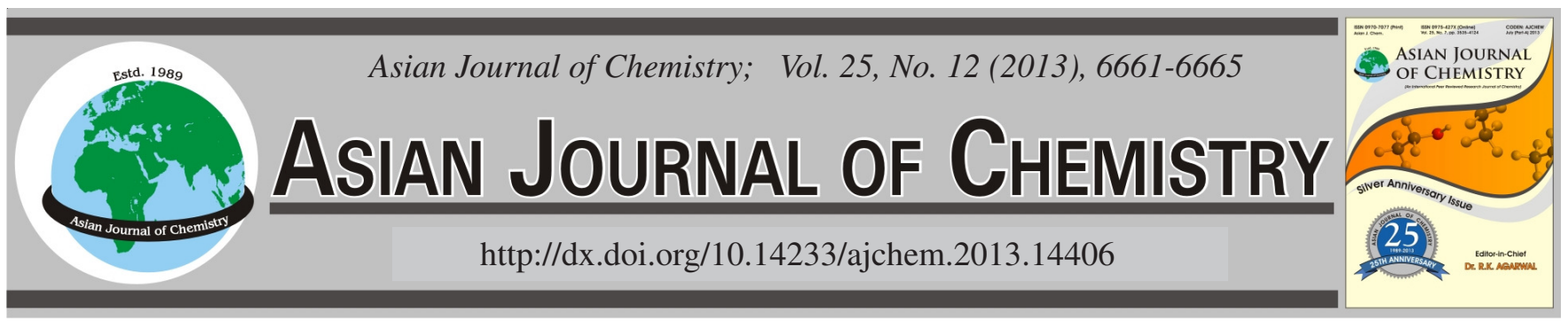

\title{
Thermodynamic Solvation of $\alpha$-Amino Butyric Acid in Aqueous Mixture of Dipolar Aprotic N,N-Dimethyl formamide
}

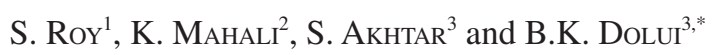

${ }^{1}$ Department of Chemistry, Shibpur Dinobundhoo Institution College, Howrah-711 102, India

${ }^{2}$ Department of Chemistry, University of Kalyani, Nadia-741 235, India

${ }^{3}$ Department of Chemistry, Visva-Bharati, Santiniketan, Birbhum-731 235, India

*Corresponding author: E-mail: bijoy_dolui@yahoo.co.in

(Received: 7 August 2012;

Accepted: 27 May 2013)

AJC-13543

Standard transfer free energies $\left(\Delta \mathrm{G}_{\mathrm{t}}^{0}(\mathrm{i})\right)$ and entropies $\left(\Delta \mathrm{S}_{\mathrm{t}}^{0}(\mathrm{i})\right)$ of $\alpha$-amino butyric acid from water to aqueous mixture of cationophilic
dipolar aprotic $\mathrm{N}, \mathrm{N}$-dimethyl formamide have been evaluated at $25^{\circ} \mathrm{C}$ from solubility measurements of the amino acid at five equidistant
temperatures $i . e .$, from 15 to $35^{\circ} \mathrm{C}$. The chemical effects of the transfer Gibbs energies $\left.\left[\Delta \mathrm{G}_{\mathrm{t}, \mathrm{ch}}^{0} \mathrm{i}\right)\right]$ and entropies of transfer $\left[\mathrm{T} \Delta \mathrm{S}_{\mathrm{t}, \mathrm{ch}}^{0}(\mathrm{i})\right]$
have been obtained after elimination of cavity effect, estimated by the scaled particle theory and dipole-dipole interaction effects, computed
by the use of Keesom-orientation expression. The chemical contribution of transfer energetics of $\alpha$-amino butyric acid are guided by the
composite effects of increased dispersion interaction, basicity effect and decreased acidity, hydrogen bonding effects, hydrophilic hydration
and hydrophobic hydration of aqueous DMF mixtures as compared to that of reference solvent, water.

Key Words: Transfer energetics, Zwitter ions, Aqua-organic solvent, Amino acid, Hydrophobic hydration.

ᄂ - - - - - - - - - - - - - - - - - - - - - - - - - - - - -

\section{INTRODUCTION}

It is well known that amino acids are fundamental structural units of proteins. The native state of a protein is determined by the nature and sequence of its constituent's amino acids as well as by the solvent environment. Much attention has been paid $^{1-5}$ to determine the various thermodynamic properties of amino acids in aqua-organic mixed solvent system.

The purposes of such studies were to gain the various aspects of protein folding - unfolding processes and protein hydration $^{6,7}$. In this regard Tanford, Nozaki and other authors ${ }^{8,9}$ reported free energies of some amino acids from water to urea from solubility measurements. Transfer free energies and entropies data of some amino acids, dipeptide, tripeptides and other biomolecules in aqueous glycerol ${ }^{10,11}$ and ethylene glycol $^{12,13}$ are also available in literature. All these experiments tried to give an idea about the relative stabilization of those amino acids and other biomolecules in aqua-organic media with respect to water and the complex solute-solvent and solvent-solvent interactions therein. In fact the environment in which the different biological processes occur may be much more 'amide like' than 'water like'. Therefore relevant data in amide solvents, like DMF in particular, are likely to be very much useful to understand biochemical processes better ${ }^{14}$.

With that end in view, in the present paper we are reporting the transfer free energies $\left[\Delta \mathrm{G}_{\mathrm{t}}^{0}(\mathrm{i})\right]$ and entropies $\left[\Delta \mathrm{S}_{\mathrm{t}}^{0}(\mathrm{i})\right]$ at $25^{\circ} \mathrm{C}$ of $\alpha$-amino butyric acid (Aba.) from water to aqueous mixture of cationophilic dipolar aprotic N,N-dimethyl formamide $\left(\mathrm{H}_{2} \mathrm{O}+\mathrm{DMF}\right)$, as determined from solubility measurements using 'formol titrimetry' at five equidistant temperatures ranging from $15-35^{\circ} \mathrm{C}$.

After eliminating effects due to cavity formation and dipole-dipole interactions and neglecting dipole-induced dipole interactions the results have been discussed in terms of dispersion interaction, acidity-basicity, hydrophilic and hydrophobic hydration and in the case of transfer entropies in terms of relative structuredness as well.

\section{EXPERIMENTAL}

$\alpha$-Amino butyric acid (Aba) (E Merck) is used after drying as described earlier ${ }^{14}$. N,N-Dimethyl formamide (LR, BDH) and water are purified by the usual method ${ }^{15}$. Aqueous mixtures of co-solvent $\left(\mathrm{H}_{2} \mathrm{O}+\mathrm{DMF}\right)$ that have been used were 20, 40, 60,80 and 100 wt $\%$. The solubility of $\alpha$-amino butyric acid is measured by formol titrimetry method. These measurements were taken at $15,20,25,30$ and $35^{\circ} \mathrm{C}$ temperatures . The lowcum-high temperature thermostat used for all measurements was capable of registering temperatures having an accuracy of $\pm 0.1^{\circ} \mathrm{C}$. Three sets of measurements were made for all the solutes by equilibrating the solutions from both above and below the required temperatures and at least two sets of 
TABLE-1

SOLUBILITIES $\left(\mathrm{mol} \mathrm{kg}^{-1}\right) \mathrm{OF} \alpha$-AMINO BUTYRIC ACID IN AQUEOUS MIXTURES OF DMF AT DIFFERENT TEMPERATURES ( $\left.{ }^{\circ} \mathrm{C}\right)$

\begin{tabular}{|c|c|c|c|c|c|}
\hline $\mathrm{Wt} \%$ of DMF & $15^{\circ} \mathrm{C}$ & $20^{\circ} \mathrm{C}$ & $25^{\circ} \mathrm{C}$ & $30^{\circ} \mathrm{C}$ & $35^{\circ} \mathrm{C}$ \\
\hline 0 & $1.702(1.850)^{\mathrm{a}}$ & 1.952 & $2.205(2.199)^{\mathrm{a}}$ & 2.534 & $2.874(2.919)^{\mathrm{a}}$ \\
\hline 20 & 1.091 & 1.195 & 1.359 & 1.458 & 1.621 \\
\hline 40 & 0.762 & 0.833 & 0.934 & 1.101 & 1.201 \\
\hline 60 & 0.467 & 0.549 & 0.638 & 0.711 & 0.814 \\
\hline 80 & 0.206 & 0.326 & 0.409 & 0.533 & 0.601 \\
\hline 100 & $0.039(0.036)^{b}$ & 0.044 & $0.048(0.045)^{\mathrm{b}}$ & 0.052 & $0.057(0.056)^{\mathrm{b}}$ \\
\hline
\end{tabular}

${ }^{\mathrm{a}}$ Reference ${ }^{20},{ }^{\mathrm{b}}$ Reference $^{24}$

measurements were made for all the solvents and the solubilities were found to agree to within $\pm 1.0-1.5 \%$.

\section{RESULTS AND DISCUSSION}

The measured solubility $(\mathrm{m})$ of the amino acid, $\alpha$-amino butyric acid on molal scale is listed in Table-1. Bates and coworkers on Tris ${ }^{16}$ and by Kundu and coworkers ${ }^{16,17}$ on nonelectrolyte like pNA, HBz and amino acids ${ }^{15}$, glycine (G), diglycine (DG) and triglycine (TG), the Gibbs energies of solutions $\left(\Delta \mathrm{G}_{\mathrm{s}}{ }^{0}\right)$ of these amino acids on molal scale were calculated for each solvent using eqn. 1 .

$$
\Delta \mathrm{G}_{\mathrm{s}}^{0}(\mathrm{i})=-\mathrm{RT} \ln \mathrm{C} \gamma=-\mathrm{RT} \ln \mathrm{C}=-\mathrm{RT} \ln \mathrm{m}
$$

where $\gamma$ is the molar activity coefficient of the solutes but taken tentatively to be unity in each solvent. Since $\alpha$-amino butyric acid is likely to be mostly in zwitter ionic forms as in nonaqueous solvent mixtures ${ }^{18,19}$, the involved activity coefficient factor -RT $\ln \gamma$ in $\Delta \mathrm{G}_{\mathrm{s}}{ }^{0}$ arising from interactions of dipolar solutes with large dipole moments may not be so small. But as there is neither the required experimental data nor any appropriate theoretical correlations for computing the same, these have been tacitly taken to be negligibly small, as is usually done for non- electrolytes ${ }^{20}$. This is because the effective contribution of activity coefficient factor -RT $\ln \gamma_{\mathrm{s}} / \gamma_{\mathrm{R}}$ in the transfer free energetics; $\Delta \mathrm{G}_{\mathrm{t}}{ }^{0}(\mathrm{i})=\Delta \mathrm{G}_{\mathrm{s}}{ }^{0}(\mathrm{i})-\Delta \mathrm{G}_{\mathrm{R}}{ }^{0}(\mathrm{i})$ in particular which is our main concern likely to be hardly significant.

The free energies, $\Delta \mathrm{G}_{\mathrm{s}}{ }^{0}$ at different temperatures are fitted by the method of least squares to an equation of the form ${ }^{11}$,

$$
\Delta \mathrm{G}_{\mathrm{s}}^{0}=\mathrm{a}+\mathrm{bT}+\mathrm{cT} \ln \mathrm{T}
$$

where $\mathrm{T}$ is the temperature in Kelvin scale. The values of the coefficients a, b, c are presented in Table-2. These are found to reproduce the experimental data within $\pm 0.04 \mathrm{~kJ} \mathrm{~mol}^{-1}$. Transfer Gibbs energies and entropies of the amino acids from water to N,N-dimethylformamide mixtures were calculated at $25{ }^{\circ} \mathrm{C}$ on mole fraction scale by using the following eqns. 3 and 4:

$$
\begin{aligned}
\Delta \mathrm{G}_{\mathrm{t}}^{0}(\mathrm{i}) & ={ }_{\mathrm{s}} \Delta \mathrm{G}_{\mathrm{s}}^{0}(\mathrm{i})-{ }_{\mathrm{R}} \Delta \mathrm{G}_{\mathrm{s}}^{0}(\mathrm{i}) \\
\Delta \mathrm{G}_{\mathrm{t}}^{0}(\mathrm{i}) & =\left(\mathrm{a}_{\mathrm{s}}-\mathrm{A}_{\mathrm{R}}\right)+\left(\mathrm{b}_{\mathrm{s}}-\mathrm{b}_{\mathrm{R}}\right) \mathrm{T} \\
& +\left(\mathrm{c}_{\mathrm{s}}-\mathrm{c}_{\mathrm{R}}\right) \mathrm{T} \ln \mathrm{T}-\mathrm{RT} \ln \left(\frac{\mathrm{M}_{\mathrm{s}}}{\mathrm{M}_{\mathrm{R}}}\right)
\end{aligned}
$$

\begin{tabular}{|c|c|c|c|c|c|}
\hline \multicolumn{6}{|c|}{$\begin{array}{c}\text { TABLE-2 } \\
\text { COEFFICIENTS a, b AND c, GIBBS ENERGIES } \Delta \mathrm{G}_{\mathrm{t}}^{\circ}(\mathrm{i}) \text { AND } \\
\text { ENTROPIES T } \Delta \mathrm{S}_{\mathrm{t}}^{\mathrm{o}} \text { (i) OF TRANSFER OF } \alpha \text {-AMINO BUTYRIC } \\
\text { ACID (ON MOLE FRACTION SCALE) IN kJ mol }{ }^{-1} \text { FROM } \\
\mathrm{H}_{2} \mathrm{O} \text { TO } \mathrm{H}_{2} \mathrm{O}-\mathrm{DMF} \text { MIXTURE AT } 25^{\circ} \mathrm{C}\end{array}$} \\
\hline $\begin{array}{c}\text { Wt } \% \text { of } \\
\text { DMF }\end{array}$ & $\mathrm{a}$ & $\mathrm{b}$ & $\mathrm{C}$ & $\Delta \mathrm{G}_{\mathrm{t}}^{\mathrm{o}}(\mathrm{i})$ & $\mathrm{T} \Delta \mathrm{S}_{\mathrm{t}}^{\mathrm{o}}(\mathrm{i})$ \\
\hline 0 & -17.73 & 0.7615 & -0.12437 & 0 & 0 \\
\hline 20 & 19.71 & -0.1656 & 0.01704 & 0.839 & -5.561 \\
\hline 40 & -71.81 & 1.9497 & -0.29985 & 0.841 & -2.602 \\
\hline 60 & 97.40 & -1.7984 & 0.25897 & 1.602 & -0.765 \\
\hline 80 & 763.91 & -16.4168 & 2.43296 & 1.775 & 17.415 \\
\hline 100 & 64.54 & -1.2530 & 0.18400 & 6.015 & -11.685 \\
\hline
\end{tabular}

and $\Delta S_{t}^{0}(i)=\left(b_{R}-b_{s}\right)+\left(c_{R}-c_{S}\right)(1+\ln T)+R \ln \left(\frac{M_{s}}{M_{R}}\right)$ here the subscript 's' and ' $\mathrm{R}$ ' refer to the co- solvent $\left(\mathrm{H}_{2} \mathrm{O}+\right.$ DMF) mixtures and reference solvent $\left(\mathrm{H}_{2} \mathrm{O}\right)$, respectively and $\mathrm{M}_{\mathrm{R}}$ and $\mathrm{M}_{\mathrm{s}}$ are the molar mass of the pure and mixed solvent, respectively. $\Delta \mathrm{G}_{\mathrm{t}}^{0}(\mathrm{i})$ and $\mathrm{T} \Delta \mathrm{S}_{\mathrm{t}}^{0}$ values of amino acid, $\alpha$-amino butyric acid thus obtained and presented in the Table- 2 . The involved uncertainties in $\Delta \mathrm{G}_{\mathrm{t}}^{0}(\mathrm{i})$ and $\Delta \mathrm{S}_{\mathrm{t}}^{0}(\mathrm{i})$ are $c a . \pm 0.05 \mathrm{~kJ}$ $\mathrm{mol}^{-1}$ and $2 \mathrm{~J} \mathrm{~K}^{-1} \mathrm{~mol}^{-1}$, respectively.

Now $\Delta \mathrm{X}_{\mathrm{t}}^{0}(\mathrm{i}$ ) (where $\mathrm{X}=\mathrm{G}$ or $\mathrm{S}$ ) may be ascribed as the sum of the following terms (assuming dipole induced dipole term to be negligibly small).

$$
\text { i.e., } \quad \Delta \mathrm{X}_{\mathrm{t}}^{0}(\mathrm{i})=\Delta \mathrm{X}_{\mathrm{t}, \mathrm{cav}}^{0}(\mathrm{i})+\Delta \mathrm{X}_{\mathrm{t}, \mathrm{dd}}^{0}(\mathrm{i})+\Delta \mathrm{X}_{\mathrm{t}, \mathrm{ch}}^{0}(\mathrm{i})
$$

Here, $\Delta \mathrm{X}_{\mathrm{t}, \mathrm{cav}}^{0}(\mathrm{i})$ indicates the transfer energy contribution of the cavity effect which is involved due to creation of cavities for the species in $\mathrm{H}_{2} \mathrm{O}$ and $\mathrm{H}_{2} \mathrm{O}+$ DMF mixed solvent system and $\Delta \mathrm{X}_{\mathrm{t}, \mathrm{d}-\mathrm{d}}^{0}(\mathrm{i})$ stands for the dipole-dipole interaction effect involving interaction between dipolar-zwitter-ionic amino acids and the solvent molecules. On the other hand, $\Delta \mathrm{X}_{\mathrm{t}, \mathrm{ch}}^{0}(\mathrm{i})$ includes all other effects such as those arising from acid-base or short-range dispersion interaction, hydrophilic or hydrophobic hydration and structural effects etc. Here $\Delta \mathrm{X}_{\mathrm{t}, \mathrm{cav}}^{0}(\mathrm{i})$ values were computed by using Scaled particle theory $(\mathrm{SPT})^{16,21}$, assuming the solutes and solvent molecules as equivalent to hard-sphere models as dictated by their respective diameter (Table-3).

$$
\Delta \mathrm{G}_{\mathrm{t}, \mathrm{dd}}^{0}(\mathrm{i})=\left({ }_{\mathrm{s}} \Delta \mathrm{G}_{\mathrm{dd}}^{0}(\mathrm{i})-{ }_{\mathrm{R}} \Delta \mathrm{G}_{\mathrm{dd}}^{0}(\mathrm{i})\right) \quad \text { and } \quad \Delta \mathrm{S}_{\mathrm{t}, \mathrm{dd}}^{0}(\mathrm{t})=
$$
$\left({ }_{\mathrm{s}} \Delta \mathrm{S}_{\mathrm{dd}}^{0}(\mathrm{i}){ }_{-}{ }_{\mathrm{R}} \Delta \mathrm{S}_{\mathrm{dd}}^{0}(\mathrm{i})\right)$ are calculated by means of the Keesomorientation expression ${ }^{22}$ for ${ }_{\mathrm{s}} \Delta \mathrm{G}_{\mathrm{dd}}^{0}(\mathrm{i})$ in a solvent $\mathrm{S}$, as given below

$$
{ }_{\mathrm{s}} \Delta \mathrm{G}_{\mathrm{dd}}^{0}(\mathrm{i})=-\left(\frac{8 \Pi}{9}\right) \mathrm{N}^{2} \mu_{\mathrm{s}}^{2} \mu_{\mathrm{x}}^{2} \sigma_{\mathrm{sx}}^{-3}(\mathrm{kT})^{-1} \mathrm{v}_{\mathrm{s}}^{-1}=\frac{\mathrm{A}}{\mathrm{T}} \mathrm{V}_{\mathrm{s}}
$$

where $\mathrm{A}=-\left(\frac{8 \Pi}{9}\right) \mathrm{N}^{2} \mu_{\mathrm{s}}^{2} \mu_{\mathrm{x}}^{2} \sigma_{\mathrm{sx}}^{-3}(\mathrm{k})^{-1}$ and $\mathrm{V}_{\mathrm{s}}=\mathrm{M}_{\mathrm{s}} / \mathrm{d}_{\mathrm{s}}$ and that of as follows: 


\begin{tabular}{|c|c|c|c|c|c|c|c|c|c|}
\hline \multicolumn{10}{|c|}{$\begin{array}{l}\text { TABLE- } 3 \\
\text { AND ENTROPIES OF TRANSFER T } \Delta \mathrm{S}_{\mathrm{t}}^{0}(\mathrm{i}), \mathrm{T} \Delta \mathrm{S}_{\mathrm{t}, \mathrm{cav}}^{0}(\mathrm{i}), \mathrm{T} \Delta \mathrm{S}_{\mathrm{t}, \mathrm{dd}}^{0}(\mathrm{i}) \text { AND } \mathrm{T} \Delta \mathrm{S}_{\mathrm{t}, \mathrm{ch}}^{0}(\mathrm{i}) \text { OF } \alpha \text {-AMINO BUTYRIC } \\
\text { ACID FROM } \mathrm{H}_{2} \mathrm{O} \text { TO } \mathrm{H}_{2} \mathrm{O}-\mathrm{DMF} \text { AT } 25^{\circ} \mathrm{C}\left(\mathrm{ON} \text { MOLE FRACTION SCALE) IN kJ mol }{ }^{-1}\right.\end{array}$} \\
\hline Wt $\%$ of DMF & $\Delta \mathrm{G}_{\mathrm{t}}^{0}(\mathrm{i})$ & $\Delta \mathrm{G}_{\mathrm{t}, \mathrm{cav}}^{0}(\mathrm{i})$ & $\Delta \mathrm{G}_{\mathrm{t}, \mathrm{dd}}^{0}(\mathrm{i})$ & $\Delta \mathrm{G}_{\mathrm{t}, \mathrm{ch}}^{0}(\mathrm{i})$ & $\mathrm{T} \Delta \mathrm{S}_{\mathrm{t}}^{0}(\mathrm{i})$ & $\Delta \mathrm{H}_{\mathrm{t}, \mathrm{cav}}^{0}(\mathrm{i})$ & $\mathrm{T} \Delta \mathrm{S}_{\mathrm{t}, \mathrm{cav}}^{0}(\mathrm{i})$ & $\mathrm{T} \Delta \mathrm{S}_{\mathrm{t}, \mathrm{dd}}^{0}(\mathrm{i})$ & $\mathrm{T} \Delta \mathrm{S}_{\mathrm{t}, \mathrm{ch}}^{0}(\mathrm{i})$ \\
\hline 0 & 0 & 0 & 0 & 0 & 0 & 0 & 0 & 0 & 0 \\
\hline 20 & 0.839 & -1.62 & 0.073 & 2.386 & -5.561 & -1.042 & 0.578 & 0.0008 & -6.140 \\
\hline 40 & 0.841 & -4.40 & 4.27 & 0.971 & -2.602 & -2.760 & 1.64 & 4.31 & -8.552 \\
\hline 60 & 1.602 & -4.98 & 5.41 & 1.172 & -0.765 & -1.949 & 3.031 & 4.86 & -8.656 \\
\hline 80 & 1.775 & -6.87 & 10.6 & -2.045 & 17.415 & -0.824 & 6.046 & 9.19 & 2.179 \\
\hline 100 & 6.015 & -8.46 & 18.2 & -4.275 & -11.685 & 14.573 & 23.033 & 15.0 & -49.718 \\
\hline
\end{tabular}

$$
{ }_{\mathrm{s}} \Delta \mathrm{S}_{\mathrm{dd}}^{0}(\mathrm{i})=\left\{\frac{\delta_{\mathrm{s}} \Delta \mathrm{G}_{\mathrm{dd}}^{0}(\mathrm{i})}{\delta \mathrm{T}}\right\}_{\mathrm{p}}
$$

i.e. $\mathrm{T}_{\mathrm{s}} \Delta \mathrm{S}_{\mathrm{dd}}^{0}(\mathrm{i})={ }_{\mathrm{s}} \Delta \mathrm{G}_{\mathrm{dd}}^{0}(\mathrm{i})[1+\mathrm{T} \alpha]$, where $\mathrm{N}$ stands for Avogadro's number, $\mu_{\mathrm{s}}, \mu_{\mathrm{x}}$ are the dipole moment of solvents and amino acid molecules, respectively (Table-3).

$\sigma_{\text {sx }}$ is the distance at which the attractive and repulsive interactions between the solvent and solute molecules are equal and is generally equal to $1 / 2\left(\sigma_{\mathrm{s}}+\sigma_{\mathrm{x}}\right)$ where $\sigma_{\mathrm{s}}$ and $\sigma_{\mathrm{x}}$ are the hard sphere diameter of co-solvent and solute molecules, respectively (Table-3) and $\alpha$ is the isothermal expansibility of the solvent and given by $\left(\delta \ln \mathrm{V}_{\mathrm{s}} / \delta \mathrm{T}\right)_{\mathrm{P}}=-\left(\delta \ln \mathrm{d}_{\mathrm{s}} / \delta \mathrm{T}\right)$. Following Marcus ${ }^{22}$ and Kim et al. ${ }^{23}$ in order to get this $\Delta \mathrm{X}_{\mathrm{t}, \mathrm{dd}}^{0}(\mathrm{i})$ term on mole fraction scale the quantity was again multiplied by the term $\mathrm{X}_{\mathrm{s}_{1}}$.

$$
X_{s 1}=\frac{X_{s}\left(\frac{\mu_{s}}{\sigma_{s}^{3}}\right)}{\left(\frac{\mu_{R}}{\sigma_{R}^{3}}\right)}
$$

which is the real mole fraction contribution due to dipoledipole interaction ${ }^{19}$. Subtraction of $\Delta \mathrm{X}_{\mathrm{t}, \mathrm{cav}}^{0}(\mathrm{i})$ and $\Delta \mathrm{X}_{\mathrm{t}, \mathrm{dd}}^{0}(\mathrm{i})$ from the total we can get $\Delta \mathrm{X}_{\mathrm{t}, \mathrm{ch}}^{0}(\mathrm{i})$ of amino acid, $\alpha$-amino butyric acid. The values of $\Delta \mathrm{X}_{\mathrm{t}, \mathrm{cav}}^{0}(\mathrm{i}), \Delta \mathrm{X}_{\mathrm{t}, \mathrm{dd}}^{0}(\mathrm{i})$ and $\Delta \mathrm{X}_{\mathrm{t}, \mathrm{ch}}^{0}(\mathrm{i})$ are presented in Table-3.

The required diameter and other solvent parameters of $\mathrm{H}_{2} \mathrm{O}$ and DMF mixtures are taken from Ref. ${ }^{22}$. The required diameter of $\alpha$-amino butyric acid (Aba.) is $6.58 \AA$ as given in Ref. ${ }^{6}$. Dipole-moment value of $\alpha$-amino butyric acid (Aba.) is $16 \mathrm{D}^{6}$.

Type of interactions between $\alpha$-amino butyric acid and solvent mixtures: Fig. 1. Represents the variation of of $\alpha$ amino butyric acid against the mole $\%$ of DMF at $25^{\circ} \mathrm{C}$. The gradual increment of value indicates that $\alpha$-amino butyric acid will be destabilized with the increased concentration of DMF in aqueous-DMF system.

Here, $\Delta \mathrm{G}_{\mathrm{t}}^{0}(\mathrm{i})$ is composed of $\Delta \mathrm{G}_{\mathrm{t}, \mathrm{cav}}^{0}(\mathrm{i}), \Delta \mathrm{G}_{\mathrm{t}, \mathrm{dd}}^{0}(\mathrm{i})$ and $\Delta \mathrm{G}_{\mathrm{t}, \mathrm{ch}}^{0}(\mathrm{i})$. [ $\Delta \mathrm{G}_{\mathrm{t}, \mathrm{d}-\mathrm{id}}^{0}(\mathrm{i})$ ] i.e., free energy change due to dipoleinduced dipole interaction, it is considered negligible].

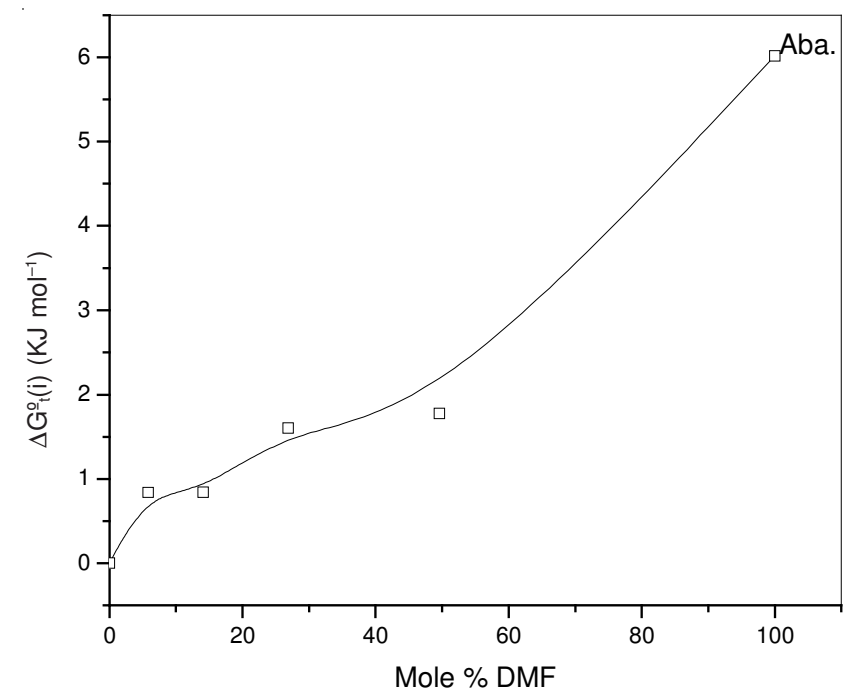

Fig. 1. Variation of $\Delta \mathrm{G}_{\mathrm{t}}{ }^{0}(\mathrm{i})$ a-amino butyric acid in aqueous $\mathrm{DMF}$ at $25^{\circ} \mathrm{C}$

The $\Delta \mathrm{G}_{\mathrm{t}, \mathrm{cav}}^{0}(\mathrm{i})$, values are gradually decreased with DMF concentration (Table-3). The $\alpha$-amino butyric acid should easily be accommodated in DMF than $\mathrm{H}_{2} \mathrm{O}$ with release of concerned energy due to the greater size of DMF $(0.498 \AA)$ than $\mathrm{H}_{2} \mathrm{O}(0.274 \AA)$.

On the other hand $\Delta \mathrm{G}_{\mathrm{t}, \mathrm{dd}}^{0}(\mathrm{i})$ (Table-3) values are increased gradually with increased mol \% of DMF. The dipole moment of DMF (3.82D) ${ }^{25}$ is greater than $\mathrm{H}_{2} \mathrm{O}(1.85 \mathrm{D})$ but the involved hard sphere diameter difference of DMF and $\mathrm{H}_{2} \mathrm{O}$ supports such variation. $\Delta \mathrm{G}_{\mathrm{t}, \mathrm{ch}}^{0}(\mathrm{i})$ of $\alpha$-amino butyric acid can be computed after subtraction of $\Delta \mathrm{G}_{\mathrm{t}, \mathrm{cav}}^{0}(\mathrm{i}), \Delta \mathrm{G}_{\mathrm{t}, \mathrm{dd}}^{0}(\mathrm{i})$ from $\Delta \mathrm{G}_{\mathrm{t}}^{0}(\mathrm{i})$. $\Delta \mathrm{G}_{\mathrm{t}, \mathrm{ch}}^{0}(\mathrm{i})$ involves the chemical interaction (i.e., H-bonding, acid-base, hard-soft, dispersion, hydrophilic hydration and hydrophobic hydration etc) between solute ( $\alpha$-amino butyric acid) and solvent molecules in this water-DMF mixture.

Fig. 2 represents the variation of $\Delta \mathrm{G}_{\mathrm{t}, \mathrm{ch}}^{0}(\mathrm{i})$ with $\mathrm{DMF}$ concentration. The $\Delta \mathrm{G}_{\mathrm{t}, \mathrm{ch}}^{0}(\mathrm{i})$ value increases up to around $10 \mathrm{~mol} \%$ of DMF in the $\mathrm{H}_{2} \mathrm{O}-\mathrm{DMF}$ system. This indicates the destabilization of $\alpha$-amino butyric acid. This occurs due to the breaking of extensive hydrogen bond between protic water and hydrophilic head of $\alpha$-amino butyric acid with the introduction of DMF in water. After that the gradual stabilization of $\alpha$-amino butyric acid occurs with the sharp decrement of $\Delta \mathrm{G}_{\mathrm{t}, \mathrm{ch}}^{0}(\mathrm{i})$ 


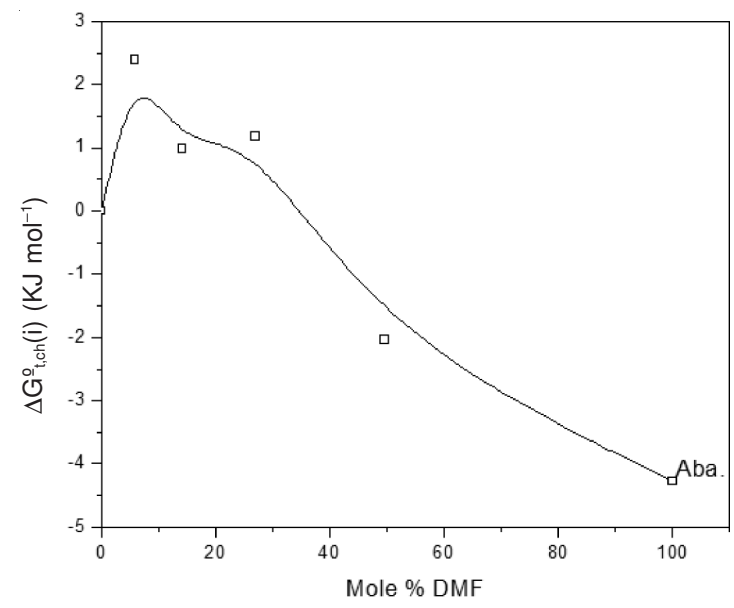

Fig. 2. Variation of $\Delta \mathrm{G}_{\mathrm{t}, \mathrm{ch}}^{0}(\mathrm{i})$ of $\alpha$-amino butyric acid in aqueous DMF at $25^{\circ} \mathrm{C}$

values with DMF concentration. Here hydrogen bonding capacity of DMF is weaker than water. This factor will destabilize the $\alpha$-amino butyric acid with the increased concentration of DMF. But the greater size of $\mathrm{DMF}^{24}$ introduces very strongly the soft-soft as well as dispersion interaction among DMF and $\alpha$-amino butyric acid [i.e., $\mathrm{CH}_{3}-\mathrm{CH}_{2}-\mathrm{CH}\left(\mathrm{NH}_{3}{ }^{+}\right)\left(\mathrm{COO}^{-}\right)$] having larger $\mathrm{R}=-\mathrm{CH}_{2}-\mathrm{CH}_{3}$.

The hydrophilic as well as hydrophobic hydration interactions are gradually reduced with decreased concentration of $\mathrm{H}_{2} \mathrm{O}$ in $\mathrm{H}_{2} \mathrm{O}$-DMF mixture. This factor may destabilize $\alpha$-amino butyric acid in aqueous DMF system.

But the increased dispersion interaction may play more dominating role over the reduced acid-base, H-bonding, hydrophilic and hydrophobic interaction involved between $\alpha$ amino butyric acid and DMF in $\mathrm{H}_{2} \mathrm{O}$-DMF mixture compared to the reference solvent, $\mathrm{H}_{2} \mathrm{O}$.

Role of $\alpha$-amino butyric acid for controlling solventsolvent interactions: Fig. 3 represents the variation of $\mathrm{T} \Delta \mathrm{S}_{\mathrm{t}}^{0}(\mathrm{i})$, of $\alpha$-amino butyric acid against mol \% of DMF in aqueous DMF. A broad minimum is shown at about $8 \mathrm{~mol} \%$ of DMF. Also broad maxima are obtained at about $50 \mathrm{~mol} \%$

DMF. Like $\Delta \mathrm{G}_{\mathrm{t}}^{0}(\mathrm{i}), \mathrm{T} \Delta \mathrm{S}_{\mathrm{t}}^{0}(\mathrm{i})$ is composed of cavity, dipoledipole and chemical interaction effects i.e.,

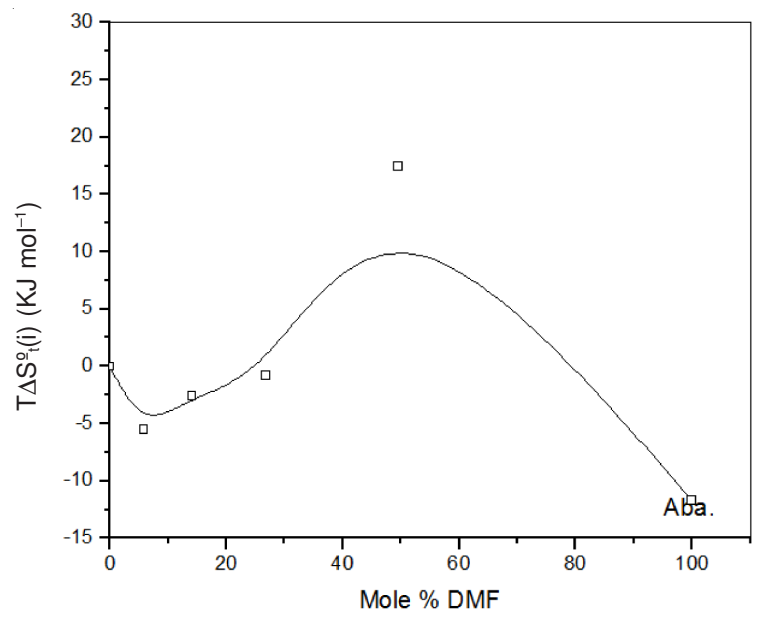

Fig. 3. Variation of $\mathrm{T} \Delta \mathrm{S}_{\mathrm{t}}^{0}(\mathrm{i})$ of $\alpha$-amino butyric acid in aqueous $\mathrm{DMF}$ at $25^{\circ} \mathrm{C}$

$$
\mathrm{T} \Delta \mathrm{S}_{\mathrm{t}}^{0}(\mathrm{i})=\mathrm{T} \Delta \mathrm{S}_{\mathrm{t}, \mathrm{cav}}^{0}(\mathrm{i})+\mathrm{T} \Delta \mathrm{S}_{\mathrm{t}, \mathrm{dd}}^{0}(\mathrm{i})+\mathrm{T} \Delta \mathrm{S}_{\mathrm{t}, \mathrm{ch}}^{0}(\mathrm{i})
$$

Now combined effect in $\mathrm{T} \Delta \mathrm{S}_{\mathrm{t}}^{0}(\mathrm{i})$ value may represents such behaviour as shown in Fig. 3. $\mathrm{T} \Delta \mathrm{S}_{\mathrm{t}, \mathrm{cav}}^{0}(\mathrm{i})$ values (Table3 ) are gradually increased with the mol \% DMF. This indicates that in presence of $\alpha$-amino butyric acid the co-solvent (DMF) and reference solvent $\left(\mathrm{H}_{2} \mathrm{O}\right)$ become separated. With the increased DMF concentrations the water molecule becomes free from $\alpha$-amino butyric acid to allow it to be accommodated by N,N-dimethyl formamide. $\mathrm{T} \Delta \mathrm{S}_{\mathrm{t}, \mathrm{dd}}^{0}(\mathrm{i})$ values (Table3) are also gradually increased with the DMF concentration. Here with the increased concentration of DMF the dipolar $\alpha$-amino butyric acid become less associated with dipolar co-solvent due to the larger size of DMF $(0.498 \AA)$ and therefore $\alpha$-amino butyric acid allow water as well as DMF molecules to be more free as the concentrations of DMF gradually increased. $\mathrm{T} \Delta \mathrm{S}_{\mathrm{t}, \mathrm{ch}}^{0}(\mathrm{i})$ is computed after subtraction of $\mathrm{T} \Delta \mathrm{S}_{\mathrm{t}, \mathrm{cav}}^{0}(\mathrm{i})$ and $\mathrm{T} \Delta \mathrm{S}_{\mathrm{t}, \mathrm{dd}}^{0}(\mathrm{i})$ from $\mathrm{T} \Delta \mathrm{S}_{\mathrm{t}}^{0}(\mathrm{i})$. Fig. 4 represents the variation of $\mathrm{T} \Delta \mathrm{S}_{\mathrm{t}, \mathrm{ch}}^{0}$ (i) of $\alpha$-amino butyric acid with increased DMF concentration in aqua-DMF mixture at $25^{\circ} \mathrm{C}$. A broad minimum at $c a .20 \mathrm{~mol} \%$ DMF indicates that water molecules adopt 3-D structure due to its extensive intermolecular hydrogen bonding (Fig. A) at lower concentration of DMF.

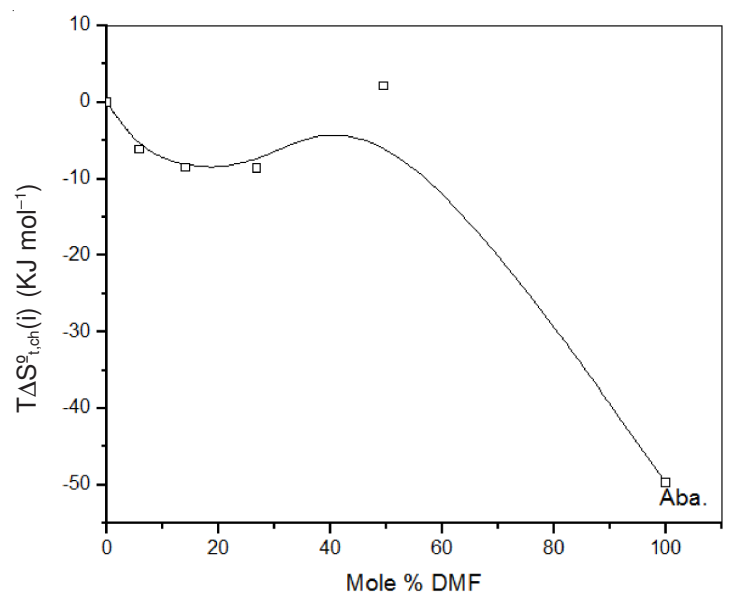

Fig. 4. Variation of $\mathrm{T} \Delta \mathrm{S}_{\mathrm{t}, \mathrm{ch}}^{\mathrm{o}}(\mathrm{i})$ of $\alpha$-amino butyric acid in aqueous DMF at $25{ }^{\circ} \mathrm{C}$

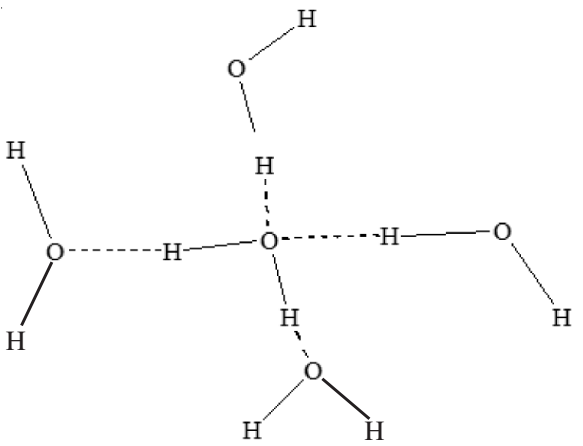

Fig. (A) 
On the other hand a broad maximum at $c a .40 \mathrm{~mol} \%$ DMF indicates that the breaking of intermolecular hydrogen bond may also be occurred as the concentration of DMF increases in this solvent mixture. With increase of DMF concentration from $40-100 \mathrm{~mol} \%$ the $\mathrm{T} \Delta \mathrm{S}_{\mathrm{t}, \mathrm{ch}}^{0}(\mathrm{i})$ values are decreased sharply. This indicate that the large sized $\alpha$-amino butyric acid induces dipolar aprotic N,N-dimethylfomamide to be dimerized (Fig. B).<smiles>C[N+](C)(C)C=O</smiles>

Fig. (B)

Here, the $\alpha$-amino butyric acid also induces the hydrophilic hydration and hydrophobic hydration to be decreased with the increased DMF concentration.

But the solute induced dispersion interaction among large size DMF molecules being the predominant factor over others the overall decrement of $\mathrm{T} \Delta \mathrm{S}_{\mathrm{t}, \mathrm{ch}}^{0}(\mathrm{i})$ values occur throughout the higher concentration of DMF in this aqua-DMF mixed solvent system.

\section{Conclusion}

It may be concluded that due to chemical interaction the larger $\alpha$-amino butyric acid will be stabilized in larger solvent DMF, with dipolar aprotic character. The zwitterionic $\alpha$-amino butyric acid induces to adopt 3-D-structuredness of water at water rich concentration in aqua-DMF solvent system.

\section{ACKNOWLEDGEMENTS}

The authors thanks to DST-SAP, UGC, Government of India and Department of Chemistry, Visva-Bharati for financial assistance and computational facilities.

\section{REFERENCES}

1. P. Das, S. Chatterjee and I.Basumallick, J. Chin. Chem. Soc., 51, 1 (2004).

2. T.S. Bani Pal, G. Singh and B.S. Lark, J. Sol. Chem., 30, 657 (2001).

3. M.N. Islam and R.K. Wadi, Phys. Chem. Liq., 39, 77 (2001).

4. S. Lapamje, In Physico-Chemical Aspects of Proteins Denaturation, Wiley Intercience; New York, p. 241 (1978).

5. F. Köseoglu, E. Kiliç and A. Dogan, Anal. Biochem., 277, 243 (2002).

6. C.B. Anfinsen and H.A. Seheraga, Adv. Protein Chem., 29, 205 (1975).

7. C. Jolicoeur and J. Boileau, Can. J. Chem., 56, 2707 (1978).

8. Y. Nozaki and C. Tanford, J. Biol. Chem., 238, 4074 (1963).

9. M. Abu-Hamdiyyah and A. Shehabuddin, J. Chem. Eng. Data, 27, 74 (1982).

10. K. Gekko and S.N. Timasheff, Biochemistry, 20, 4677 (1981).

11. S. Ganguly and K.K. Kundu, J. Phys. Chem., 97, 10862 (1993).

12. S. Roy, K. Mahali and B.K. Dolui, Biochemistry: An Indian J., 3, 71 (2010).

13. K. Majumder (Sengupta) and S.C. Lahiri, J. Indian Chem. Soc., 74, 382 (1997).

14. H. Talukdar, S.P. Rudra and K.K. Kundu, Can. J. Chem., 66, 461 (1988).

15. J. Datta and K.K. Kundu, J. Phys. Chem., 86, 4055 (1982).

16. S.C. Dutta and S.C. Lahiri, J. Indian Chem. Soc., 72, 315 (1995).

17. R. Sinha, S.K. Bhattacharya and K.K. Kundu, J. Mol. Liq., 122, 95 (2005).

18. R.A. Pierotti, J. Phys. Chem., 67, 1840 (1963).

19. Y. Marcus, Ion Solvation, John Willy and Sons, New York (1985).

20. S. Roy, K. Mahali and B.K. Dolui, Biochemistry-An Indian J., 3, 63 (2009).

21. B.K. Dolui, S.K. Bhattacharya and K.K. Kundu, Indian J. Chem., 45A, 2607 (2006).

22. N.E. Hill, W.E. Baughan, A.H. Price and M. Davics, Dielectric Properties and Moleculer Behaviour. Van Nostrand Reinhold Comp, London (1969).

23. K. Mahali, S. Roy and B.K. Dolui, J. Biophys. Chem., 2, 185 (2011).

24. R. Sinha and K.K. Kundu, J. Mol. Liq., 111, 151 (2004).

25. J. Datta and K.K. Kundu, Can. J. Chem., 61, 625 (1983). 